\title{
IAMJ
}

INTERNATIONAL

AYURVEDIC

MEDICAL JOURNAL

\section{MANAGEMENT OF INFERTILITY DUE TO HYDROSALPINX WITH BOH BY AYURVEDIC REGIME: A CASE STUDY}

\author{
Poonam Kumari ${ }^{1}$, Hetal H. Dave ${ }^{2}$, Poonam Choudhary ${ }^{3}$, Sonu $^{4}$ \\ ${ }^{1}$ MS Scholar, Final Year, Department of Prasuti-Stri Roga, National Institute of Ayurveda, Jaipur, Rajasthan, India \\ ${ }^{2}$ Associate Professor, Department of Prasuti-Stri Roga, National Institute of Ayurveda, Jaipur, Rajasthan, India \\ ${ }^{3,4}$ Lecturer, Department of Prasuti-Stri Roga, National Institute of Ayurveda, Jaipur, Rajasthan, India
}

Corresponding Author: azadpoo77@gmail.com

\section{https://doi.org/10.46607/iamj2709022021}

(Published online: February 2021)

Open Access

(C) International Ayurvedic Medical Journal, India 2021

Article Received: 06/01/2021 - Peer Reviewed: 18/01/2021 - Accepted for Publication: 23/01/2021

\section{(A) Check for updates}

\section{ABSTRACT}

We report a case of a 33 years old female patient anxious for issues since 2 years. Patient was having Bad Obstetric History $(\mathrm{BOH})$ in her previous 2 pregnancies with history of Ectopic pregnancy in her last pregnancy for which linear salpingostomy was done. Patient underwent diagnostic investigations and procedures to rule out the cause. She was found to have Bilateral Hydrosalpinx in her HSG findings. So, the treatment was planned accordingly, and she was treated with Ayurvedic regimen consisting of Shodhana and Shamana therapy. HSG was repeated 6 months after treatment which was found to be normal with Bilateral patent tubes and she was managed to conceive successfully after treatment. Though she was a $\mathrm{K} / \mathrm{C} / \mathrm{O} \mathrm{BOH}$ also, so she was provided all the necessary advice and examinations in her Antenatal period including Masanumasika Garbhini Paricharya and she delivered healthy female child of $2.8 \mathrm{kgs}$ on 21.11.2020. So, implementation of Ayurvedic approach with X ray HSG resulted in successfully treating this case without tubal corrective surgery.

Keywords: Hydrosalpinx, Tubal blockage, Infertility 


\section{INTRODUCTION}

Infertility is defined as a failure to conceive within one or more years of regular unprotected coitus ${ }^{1}$. Various male and female causative factors have been described for infertility out of which tubal factor in female is one of the most important factor accounting for $20-25 \%{ }^{2}$ of infertility cases. Tubal factor includes damage or obstruction of the fallopian tubes and are usually associated with previous PID or previous pelvic or tubal surgery $^{3}$. Hydrosalpinx is one of the tubal factors contributing to infertility. Hydrosalpinx is collection of mucus secretion into fallopian tubes ${ }^{4}$. Hydrosalpinx can be unilateral or bilateral. The blocked tubes cause infertility $^{5}$ as the blocked tubes don't let the ovum and sperm converge, thus making fertilization impossible ${ }^{6}$. The treatment modalities related to hydrosalpinx in modern science include tubal corrective surgery. Different types of tubal corrective surgeries are performed either through laparotomy or laparoscopic approach includes tubal re-anastomosis, salpingostomy, tubal occlusion, salpinolysis ${ }^{7}$ etc.

According to Ayurveda female infertility has been explained under Vandhyatawa. Acharya Sushruta has mentioned the essential factors needed for conception as Ritu (period near ovulation), Kshetra (female reproductive system), Ambu (nourishing substances), Beeja (sperm and ovum $)^{8}$. Impairment or dysfunction of any of above factor may lead to infertility. Infertility due to tubal factor can be considered under Kshetra vikriti. Considering dosha involvement in tubal blockage due to hydrosalpinx, it can be considered as Tridoshaja vyadhi. Vata is responsible for Dhatugati ${ }^{9}$. Kapha contributes to tubal blockage due to its Avrodhaka and Sophajanka properties. Kapha vitiated due to its Sthira Guna $^{10}$ can lead to tubal blockage. Pitta vitiated with its drava guna ${ }^{11}$ may lead to accumulation of drava (serous fluids) thus causing hydrosalpinx.

\section{Rationality of selection of drug and procedure:}

Infertility due to Hydrosalpinx is a Tridoshaja, Sanga strodushti janya vyadhi caused due to accumulation of excessive dravas (serous fluids) in the fallopian tubes. Considering this the treatment should be Stroshodhaka, Shoshaka (absorbent) and tridosha shamaka. As Vata is a main cause behind all the gynecological diseases so
Yoga Basti therapy is considered to be supreme to pacify vata and also for Strotoshodhana. Bala Beeja churna and Amalki churna are also suitable to treat to hydrosalpinx because of their various properties which will be discussed later.

\section{Case Report}

This is a case report of a female patient of age 33 years who visited OPD of National Institute of Ayurveda, Jaipur (NIA) on 23.08.19 with the complaint of unable to conceive since 2 years. She was also having associated complaint of constipated bowel (on and off) sometimes.

Married life: 3.5 years

Active married life: 3.5 years

Obstetric History:

O.H: $\mathrm{G}_{2} \mathrm{P}_{0} \mathrm{~L}_{0} \mathrm{~A}_{2}$

$\mathbf{G}_{\mathbf{1}}$ : Induced abortion of GA approximate 8 weeks of gestation, because of absence of fetal cardiac activity, $\mathrm{D} \& \mathrm{C}$ was done, 3 years ago

$\mathbf{G}_{\mathbf{2}}$ : Ectopic pregnancy, Linear salpingotomy was done, 2 years ago

Menstrual History: Patient attained menarche at 13 years of age. She was having regular menstrual cycle with the interval of 28-30 days, 4-5 days of duration, normal flow, mild pain sometime and no foul smell.

Her L.M.P was 21.08.2019.

Clinical History: Patient had undergone several allopathic treatments for infertility with many diagnostic procedures like X-ray HSG, Diagnostic Hysteroscopy and Laparoscopy.

X- ray HSG: Her X- ray HSG report done on (17.03.2019) was suggestive of bilateral mild Hydrosalpinx.

USG was suggestive of normal study.

Hysteroscopy was suggestive of normal uterine cavity, normal endometrium.

Laparoscopy revealed that CPT was present Her AMH level was also normal.

TB PCR done was found to be negative.

TORCH test done was found to be negative.

Husband's semen analysis was also normal. 


\section{Personal History:}

- Appetite: Normal

- Sleep: Sound Sleep

- Bowel habits: Constipation (on an off)

- Micturition: Clear

- Allergic History: No

\section{Dashvidha Pariksha:}

- Prakuti: Vata-pittaja

- Vikruti: Vishmasamveta

- Sara: Rasa

- Samhana: Madhyama

- Pramana: Madhyama
- Satmya: Madhyama

- Ahara Shakti:

- Abhyavahrana Shakti: Madhyama

- Jarana Shakti: Madhyama

- Vyayama Shakti: Madhyama

- Vaya: Madhyama

Physical examination:

- Built: Moderate

- Height: 5' 5',

- Weight: $57 \mathrm{~kg}$

- $\quad$ BMI: $20.9 \mathrm{~kg} / \mathrm{m}^{2}$

- Pulse: 80/min

- B.P: $110 / 70 \mathrm{~mm}$ of $\mathrm{Hg}$ 


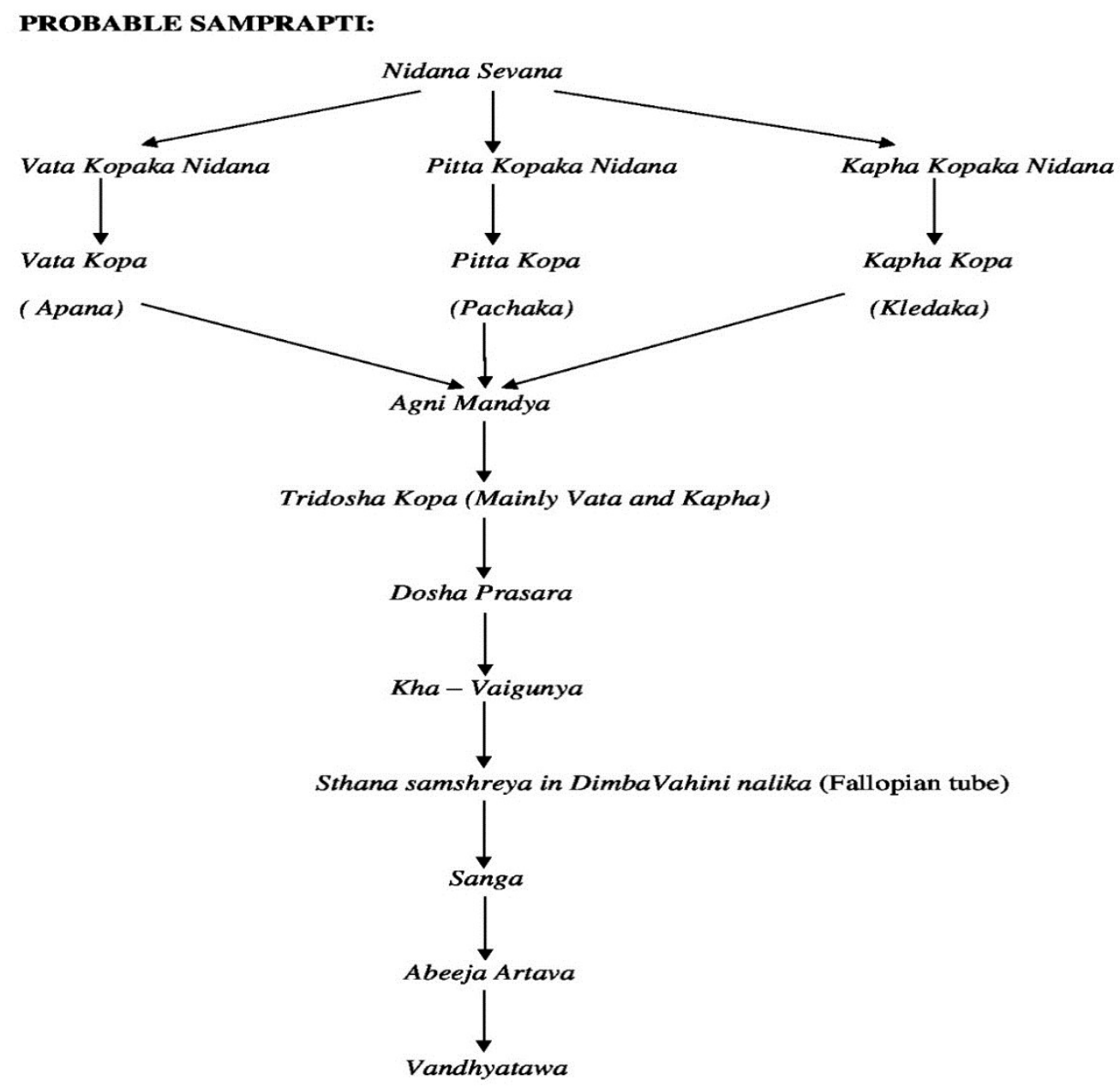

Treatment Plan: Treatment plan was to administer Shodhana (Yoga Basti) and Shamana chikitsa. Yoga basti therapy including 8 bastis with alternative Aasthapana and Anuvasana Basti along with that Shamana chikitsa with oral medicine was administered for
6 consecutive cycles explained in Table 1 and Table 2 . Pathya including Rajaswalacharya and Apathyas were also explained to patient. 


\section{Detailed Posology of Yoga Basti And Oral Medicine Administered:}

Table 1: Yoga Basti Contents

\begin{tabular}{|l|l|}
\hline Aasthpana Basti & $-\quad$ Makshika (Madhu) $-30 \mathrm{ml}$ \\
& $-\quad$ Saindhava lavana $-5 \mathrm{gm}$ \\
& $-\quad$ Dashmoola taila $-50 \mathrm{ml}$ \\
& $-\quad$ Shatapushpa $\mathrm{kalka}-50 \mathrm{gm}$ \\
Anuvasana Basti & $-\quad$ Dashmoola $\mathrm{kwatha}-300 \mathrm{ml}$ \\
\hline
\end{tabular}

Table 2: Oral Medication Administered

\begin{tabular}{|l|l|l|l|}
\hline Oral medicine & Dose & Anupana & Time \\
\hline Bala beeja Churna & $5 \mathrm{gm}$ & Go Dugdha & Before meal \\
\hline Amalki Churna & $3 \mathrm{gm}$ & Water & After meal \\
\hline
\end{tabular}

\section{Preparation of Bastis for Yoga Basti:}

Asthapana Basti: Asthapana Basti was prepared by adding the contents serially as per the method mentioned by Vridha vagbhata: Makshika, Lavana, Sneha, Kalka, Kwatha. Makshika 30ml was added to a round bowl following which 5 gm of Saindhava lavana was added and was mixed properly until the disappearance of sound. Following above Lukewarm Dashmoola taila $50 \mathrm{ml}$ was added and mixed until the homogenous mixture was formed. Shatapushpa kalka $50 \mathrm{gm}$ was added to it following which lukewarm Dashmoola Kwatha $350 \mathrm{ml}$ was added and was mixed until the formation of homogenous mixture. This is how the Asthapana Basti was prepared.

Anuvasana Basti: Anvasana Basti was prepared simply by adding $1 \mathrm{gm}$ of Saindhava lavana to lukewarm $60 \mathrm{ml}$ of Dashmoola taila.

\section{Administration of Basti Dravya:}

Timing of administration: Basti was administered following cessation of menstruation on day $8^{\text {th }}$ of menstrual cycle. Asthapana Basti was administered empty stomach whereas Anuvasana Basti was administered just after intake of food.

Method of administration: Anuvasana Basti was administered with the help of a syringe and Asthapana Basti was administered with the help of an enema pot, both fitted with rubber catheter number 8 and filled with prepared Basti Dravya. Patient was asked to lie in left lateral position with right leg flexed at knee joint and catheter lubricated with oil was introduced into the anus and Basti dravyas (Kwatha and Oil) were administered.

Following Basti administration patient was asked to lie in supine position: her buttocks, palm, soles were gently tapped.

\section{Instructions given during Basti therapy:}

- To take Lukewarm water

- To avoid suppressing natural urges, sleeping during daytime

- To avoid travelling and doing heavy exercise

- To avoid overeating, fast food, oily and processed food

\section{Outcome:}

- Patient was administered the above-mentioned treatment for 6 consecutive cycles with regular follow ups during the treatment schedule.

- HSG was repeated after 6 months of treatment on 1.03.2020 and it was suggestive of normal study with bilateral fallopian tubes being normal.

- Patient missed her periods on 23.03.2020 and did her UPT which was found to be positive.

- USG for viability was carried out which showed Intrauterine gestation of 6 weeks with yolk sac present measuring $4.5 \mathrm{~mm}$, presence of cardiac activity 107bpm.

- Patient was given proper Antenatal care including all the examinations and advises. She delivered a healthy female child of wt. $2.8 \mathrm{~kg}$ on 21.11.2020. 

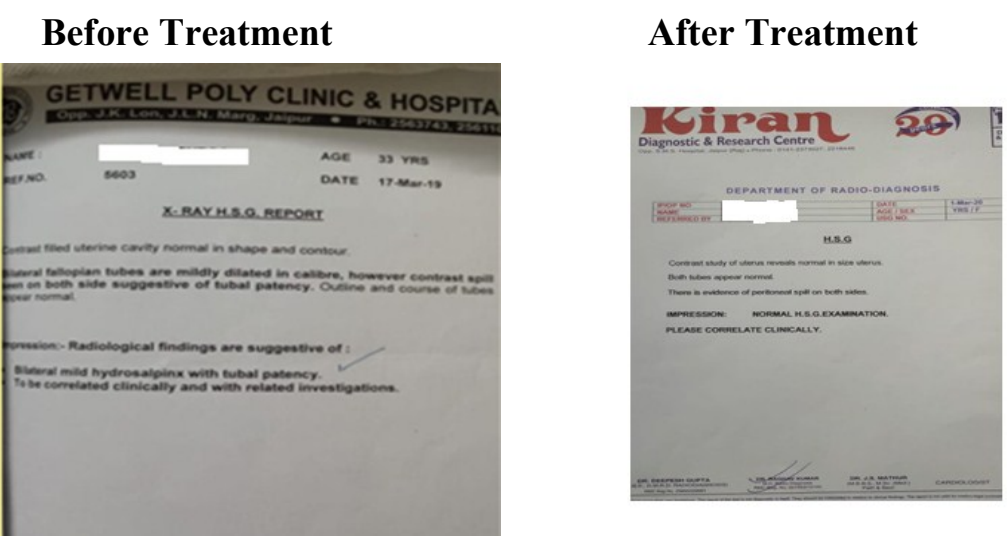

\section{After Treatment}

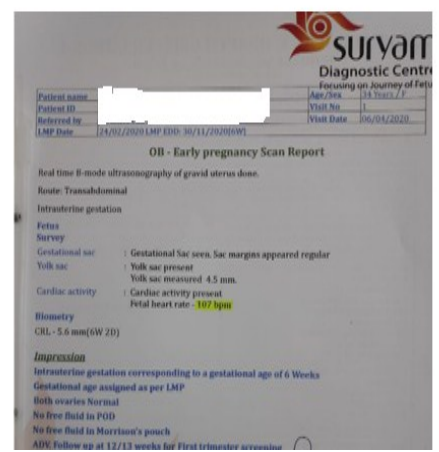

\section{DISCUSSION}

Vandhyatava due to Hydrosalpinx can be considered to be Tridoshaja vyadhi with Vata and Kapha predominance. In Ayurveda, Chikitsa is done on the concept of Samprapti vighatana, so the Samprapti ghtaka of this case study can be laid out as follows:

Dosha: Aapana \& Samana Vata, Pachka Pitta, Kledaka Kapha

Dushya: Rasa Dhatu, Artava updhatu

Agni: Dhatawagni mandya

Strotas: Artava vaha

Strotodushti: Sanga

Vyaktisthana: Artavavaha Strotas

Avayava: Dimbavahini nalika

Considering above, the main line of treatment planned was Stroto shodhaka, Tridosha Shamaka, Agni deepaka and Vatanulomaka. Yoga Basti has been mentioned to be summation of 8 Bastis by Achrya Charaka starting with one anuvasana followed by 3 asthapana and 3 anuvasna alternatively and 1 anuvasna at last ${ }^{12}$. Asthpana basti is mentioned to cure all the diseases (Sarva gada apaha), able to serve all purposes (Sarva arthkari) ${ }^{13}$. Anvasana is mentioned to have Pushpa phalaprada $^{14}$ property. Dashmoola is Tridosha shamaka, chiefly Vata. Also, it possesses Shothahara (Anti-inflammatory), Ama pachana (antioxidant or free radical scavenging properties) may be leading to intervene the inflammatory changes and leading to samprapti vighatana. Saindhava lavana due to its Sukshama guna reaches up to the micro channels of body and because of its teekshana guna it breaks the morbid malas and dosha sanghata leading to Strotoshodhana. Madhu due to its Yogavahi property leads to proper absorption of Basti dravya; assimilation by the body properly. Being Kaphahara it may be leading to dissolution of Avrodha caused by Kapha dosha and resulting in Strotoshodhana and Samprapti vighatana. Bala is mentioned to have Grahi, Snigdha, Sheeta Guna ${ }^{15}$. Acharya charaka mentioned it in Prajasthapana Mahakshya ${ }^{16}$ and to be best among Sangrahi, Balya and Vatahara ${ }^{17}$ dravyas. While defining different dravyas Acharya Sharandghara mentioned that Grahi dravya has deepana, pachana, dravashoshka ${ }^{18}$ (absorbent) properties. Hydrosalpinx refers to the fallopian tubes that are being blocked by watery fluid, so probably Bala due to its Grahi property is helpful in absorbing the watery fluids thus making fallopian tubes patent for fertilization and treating infertility caused by hydrosalpinx.

Amlaki is Tridoshahara, Rasayana, Vrishya, Sarvadoshaghana. It is known to be natural antioxidant. Contents present in it like tannins, alkaloids, phenolic compounds, amino acids and carbohydrates are proved to be having antipyretic activity. Extract of fruits of Embelia officinalis possess anti-inflammatory and analgesic property ${ }^{19}$. As Hydrosalpinx is considered to be end stage of pyosalpin ${ }^{20}$ so antipyretic and anti-inflammatory properties of Amalki would have resulted in suppression of inflammatory reaction with secretion of pus and thus reverting back the pathology underlying of tubal blockage due to hydrosalpinx.

\section{CONCLUSION}

Infertility due to tubal blockage is one of the common causes. In modern science well established treatment 
for infertility are there but when it comes to tubal factors there is not yet any satisfactory treatment available. This Ayurvedic regime possessing anti-inflammatory, antipyretic, antioxidant, absorbent properties and shodhana therepy is helpful in successfully managing infertility due to hydrosalpinx (tubal blockage). This will also be helpful in preventing complications and bad outcomes like adhesions, ectopic pregnancy etc. related to the operative procedures of tubal corrective surgeries.

\section{REFERENCES}

1. Hiralal Konar, DC Dutta's Textbook of Gynecology, $7^{\text {th }}$ edition, Reprint edition; 2016, Chp 27 Pg no. 186

2. Hiralal Konar, DC Dutta's Textbook of Gynecology, $7^{\text {th }}$ edition, Reprint edition; 2016, Chp 17 Pg no. 188

3. Jonathan S. Berek, Novak's Gynecology, $13^{\text {th }}$ edition, Reprint edition; 2002. Lippincott Williams \& Wikkins, Chapter no. 27

4. Hiralal Konar, DC Dutta's Textbook of Gynecology, $7^{\text {th }}$ edition, Reprint edition; 2016,Chp 13 Pg no. 139

5. https://www.google.com/search? $\mathrm{q}=5 \mathrm{http} \% 2 \mathrm{~F} \% 2 \mathrm{Fen}$.wi kipedia.org\%2Fwiki\%2FHydrosal-

pinx\&oq $=5 \mathrm{http} \% 2 \mathrm{~F} \% 2 \mathrm{Fen}$. wikipe-

dia.org\%2Fwiki\%2FHydrosal-

pinx\&aqs $=$ chrome..69i57j69i58.10085j0j4\&sourceid $=\mathrm{c}$ hrome $\& \mathrm{ie}=\mathrm{UTF}-8$

6. https://www.google.com/search? q=6+http $\% 3 \mathrm{~A} \% 2 \mathrm{~F} \% 2$ Fen.wikipedia.org\%2Fwiki\%2FFallopian_tube_obstruction\&oq $=6 \% 09 \mathrm{http} \% 3 \mathrm{~A} \% 2 \mathrm{~F} \% 2 \mathrm{Fen}$. wikipedia.org\%2Fwiki\%2FFallopian_tube_obstruction\&aqs $=$ chrome..69i57j69i58.4499j0j9\&sourceid $=\mathrm{ch}$ rome\&ie $=\mathrm{UTF}-8$

7. https://www.google.com/search? $\mathrm{q}=7+\mathrm{http} \% 3 \mathrm{~A} \% 2 \mathrm{~F} \% 2$ Fen.wikipedia.org\%2Fwiki\%2FTuboplasty\&oq $=7 \% 09 \mathrm{http} \% 3 \mathrm{~A} \% 2 \mathrm{~F} \% 2 \mathrm{Fen}$. wikipedia.org\%2Fwiki\%2FTuboplasty\&aqs $=$ chrome..69i57j69i58.7033j0j9\&sourceid $=$ chrome\&ie $=$ UTF -

8. Prof. PV Tiwari, Ayurvediya PrasutiTantra avum Stri Roga, Volume I, Prasuti Tantra, reprint Edition. Varanasi: Chaukhambha orientalia; 2017, Pg no. 86

9. Charaka Sutra Sthana. In: Pandit Kashi Nath Shastri \& Dr. Gorkhnath Chaturvedi, editors. Charaka Samhita. Revised edition. Varanasi (India): Chaukhambha Bharati Academy; 2016 Chapter 18, Shaloka no. 49, Pg no. 374

10. Charaka Sutra Sthana. In: Pandit Kashi Nath Shastri \& Dr. Gorkhnath Chaturvedi, editors. Charaka Samhita. Revised edition. Varanasi (India): Chaukhambha Bharati Academy; 2016 Chapter 1, Shaloka no. 61, pg no. 37
11. Charaka Sutra Sthana. In: Pandit Kashi Nath Shastri \& Dr. Gorkhnath Chaturvedi, editors. Charaka Samhita. Revised edition. Varanasi (India): Chaukhambha Bharati Academy; 2016 Chapter 1, Shaloka no. 60, Pg no. 36

12. Charaka Sidhi Sthana. In: Pandit Kashi Nath Shastri \& Dr. Gorkhnath Chaturvedi, editors. Charaka Samhita. Revised edition. Varanasi (India): Chaukhambha Bharati Academy; 2016 Chapter 1, Shaloka no. 47-48, Pg no. 973

13. Charaka Sidhi Sthana. In: Pandit Kashi Nath Shastri \& Dr. Gorkhnath Chaturvedi, editors. Charaka Samhita. Revised edition. Varanasi (India): Chaukhambha Bharati Academy; 2016 Chapter 1, Shaloka no. 27-28, Pg no. 969

14. Charaka Sidhi Sthana. In: Pandit Kashi Nath Shastri \& Dr. Gorkhnath Chaturvedi, editors. Charaka Samhita. Revised edition. Varanasi (India): Chaukhambha Bharati Academy; 2016 Chapter 1, Shaloka no. 27-28, Pg no. 969

15. Bhavaprakasha Nighantu In: Prof. Krishna Chandra Chunekar \& Late Dr. Ganga Sahay Pandey. Reprint edition. Varanasi (India): Chaukhmaba orientalia; 2013, Guduchyadi Varga, Pg no. 353

16. Charaka Sutra Sthana. In: Pandit Kashi Nath Shastri \& Dr. Gorkhnath Chaturvedi, editors. Charaka Samhita. Revised edition. Varanasi (India): Chaukhambha Bharati Academy; 2016 Chapter 4, Shalok no. 49, Pg no. 87

17. Charaka Sutra Sthana. In: Pandit Kashi Nath Shastri \& Dr. Gorkhnath Chaturvedi, editors. Charaka Samhita. Revised edition. Varanasi (India): Chaukhambha Bharati Academy; 2016 Chapter 25, Sholoka no. 40, Pg no. 467

18. Shrangdhara Samhita In: Dr. Shailja Shrivastava. Revised edition. Varanasi (India): Chaukhambha Orientalia; 2016 Chapter 4, Shloka 12, Pg no. 32

19. Perianayagam JB, Sharma SK, Joseph A, Christian AJ. Evaluation of antipyretic and analgesic activity of Emblica officinalis Gaertn. J Ethnopharmacol. 2004; 95(1):83-5

20. Hiralal Konar, DC Dutta's Textbook of Gynecology, $7^{\text {th }}$ edition, Reprint edition; 2016, Chp 13 Pg no. 140

\section{Source of Support: Nil Conflict of Interest: None Declared}

How to cite this URL: Poonam Kumari et al: Management Of Infertility Due To Hydrosalpinx With $\mathrm{BOH}$ By Ayurvedic Regime: A Case Study. International Ayurvedic Medical Journal \{online\} 2021 cited February, 2021\} Available from: http://www.iamj.in/posts/images/upload/491_497.pdf 